\title{
TROPHIC STRUCTURE OF FISH ASSEMBLAGES IN THE LOWER MIRANDA RIVER, PANTANAL, MATO GROSSO DO SUL STATE, BRAZIL
}

\author{
RESENDE, E. K. de \\ Centro de Pesquisa Agropecuária do Pantanal, EMBRAPA, Rua 21 de Setembro, 1880, \\ CEP 79320-900, Corumbá, MS, Brazil \\ Correspondence to: Emiko Kawakami de Resende, Centro de Pesquisa Agropecuária do Pantanal, EMBRAPA, \\ Rua 21 de Setembro, 1880, CEP 79320-900, Corumbá, MS, Brazil, \\ e-mail: emiko@cpap.embrapa.br \\ Received March 4, 1999 - Accepted September 14, 1999 - Distributed August 31, 2000
}

(With 1 figure)

\begin{abstract}
Of a total of 101 fish species caught in the Lower Miranda River floodplain, 29 were omnivorous, 16 ichthyophagous, 12 herbivorous, 18 detritivorous, 8 zooplanktophagous, 7 insectivorous, 2 lepidophagous, 4 ichthyophagous/insectivorous and 4 zooplanktophagous/insectivorous. Almost half of the species belong to omnivorous and detritivorous trophic guilds. The same is not true when biomass is considered. The number of fish species by trophic guild didn't change along the year whereas the biomass changed significantly. The frequency of abundant fish species was not the same for the sampled environments.
\end{abstract}

Key words: Pantanal, fish assemblages, trophic structure.

\section{RESUMO}

\section{Estrutura trófica das comunidades de peixes do baixo Rio Miranda, Pantanal, Mato Grosso do Sul, Brasil}

Das 101 espécies de peixes capturadas na planície de inundação do baixo Rio Miranda, 29 foram onívoras, 16 ictiófagas, 12 herbívoras, 18 detritívoras, oito zooplanctófagas, sete insetívoras, duas lepidófagas, quatro ictio/insetívoras e quatro zoo/insetívoras. Quase a metade das espécies pertence às guildas tróficas onívora e detritívora. $\mathrm{O}$ mesmo não é verdadeiro quando se considera o número de exemplares e seu peso (biomassa). O número de espécies por guilda trófica não variou ao longo do ano, ao passo que o número de peixes e respectivo peso variou significativamente. A freqüência de espécies abundantes variou entre os ambientes amostrados.

Palavras-chave: Pantanal, comunidades de peixes, estrutura trófica.

\section{INTRODUCTION}

Studies on trophic structure of fish assemblages are not common in Brazil due to the difficulty in sampling all the existing fishes in a water body and specially to the hard work involved in determining the feeding habits of all the fishes captured. Exceptions are studies in Tibagi River (Bennemann, 1996), in a oxbow lake in Mogi-
Guaçu River (Meschiatti, 1995, in Bennemann, 1996), in Paraná River (Agostinho et al., 1997; Hahn et al., 1997, 1998) and in Iguaçu River (Agostinho et al., 1997), from South and Southeast Brazil. For the Pantanal, this study is pioneer and is part of a larger study performed in the Miranda River to understand the relationships between the river and its floodplain to give support to fishery management programs. May et al. (1979), using 
a simple model, discuss the way multispecies food webs respond to the harvesting of species at different trophic levels, a question that needs to be addressed if we desire sustainable management programs to Pantanal fisheries. Sport fishing is growing fast in the South Pantanal rivers, and nowadays captures $70 \%$ of the total landings (Catella et al., 1996). The Miranda River produces $1 / 3$ of the total catches, half caught by sportfishermen and half by commercial fishing. So, the understanding of the trophic structure of these fish assemblages is one of the key aspects for their conservation.

\section{STUDY AREA}

The present work was conducted in the lower Miranda River, near its confluence with the Paraguay River, located in the Pantanal, one of the biggest freshwater floodplains in the world (Fig. 1). In its final stretch, before entering the Paraguay River, due to a very low gradient, the Miranda River is very meandric, with a diffuse drainage, and a lot of dead arms and small secondary watercourses, regionally known as "corixos" and "vazantes". Corixos are permanent watercourses with their own beds, while vazantes are temporary courses without a proper riverbed.

The fishes were sampled in four environments in the lower Miranda River, two dead arms, one "vazante" and one small pond, formed by the extraction of soil for road construction. The first, named "Braço Morto Acima" (station 1), is located upstream "Passo do Lontra", through which the State Road, MS-228, crosses the Miranda River. It is an old arm left by the Miranda River during its life history. It stays connected to the river, through a shallow mouth, all over the year, except in very dry years, from October to December. This old arm is cut into two stretches in the dry months (November/December). In the banks near the river, aquatic rooted macrophytes or plants resistant to flooding predominate; in the opposite bank, typical riparian vegetation occurs. Depending on the flooding, varying amounts of floating macrophytes can be found covering the water surface. The depth ranges from 1 to 3 meters, during the dry and flooding seasons.

The "Braço Morto Abaixo", fish sampling station 2 (Fig. 1), is also an old river arm, located on the right side of the Miranda River, $3 \mathrm{~km}$ downstream "Passo do Lontra". The vegetation is similar to the first arm, with more dense riparian vegetation on the right side of the arm, whose inner limits are difficult to distinguish in the flooding season. The depth ranges from 0.5 to 3 meters during the dry and wet season. In 1989, the connection to the river was cut in November, and the dead arm remained isolated until the following flooding season (February).

The sampling station 3, "Vazante do Morro do Azeite", is the drainage line of the Miranda River overflowing waters during the flooding season. It can dry out or remain with water, depending on the flooding of each year. During the years 1989 and 1990, when the drought was not severe, it remained with water. A large amount of water surface is covered with aquatic plants, basically with floating Eichornia azurea. The submerged aquatic plants were mainly Cabomba pyauhiensis and Utricularia foliosa. Riparian vegetation is not found along this vazante.

The fish sampling station 4, "Baía Cinza", was formed by the soil extraction for the State road construction, MS-228. Its size ranged from 1 to 1.5 hectares, depending on the year and on the month of the year, according to the rains and the Miranda River flooding. It is very shallow, reaching 1.5 meters deep in the deeper areas.

The bottom is covered with a large layer of very soft organic sediment. Phytoplankton and small crustaceans were very abundant in this small pond. Vegetation is very poor around the pond, with some Eichornia spp, Ipomea fistulosa and grasses. In years of very strong flood, such as in 1988 - the biggest flood of the century in the Pantanal, this small pond was flooded by the Miranda River overspreading waters and also received new fishes coming with the flood.

\section{MATERIAL AND METHODS}

The fishes were sampled at four stations in the floodplain of the lower Miranda River, as shown in Fig. 1. The fish samples were taken monthly between September/1989 and March/1990 and bimonthly, between March/1990 and November/ 1990.

Due to specific characteristics of each sampling station, different sampling gears were used. 


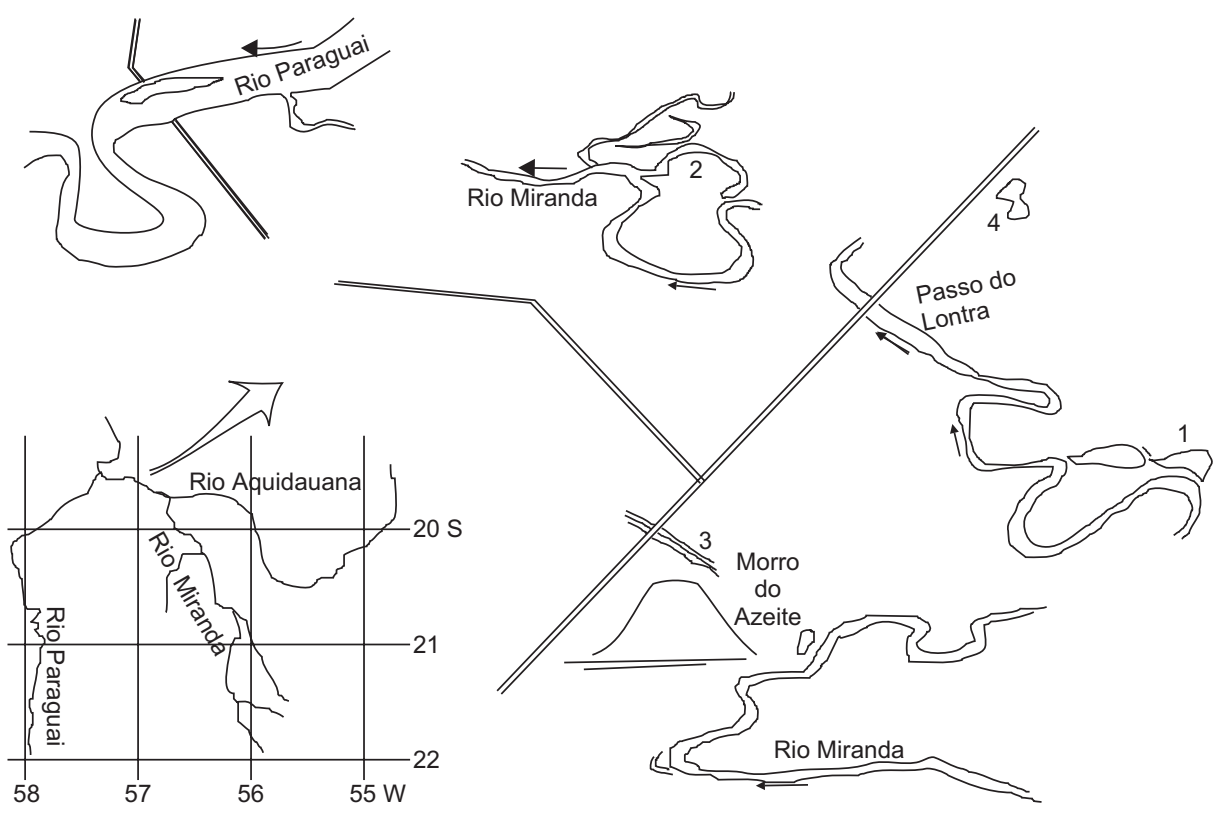

Fig. 1 - Fish sampling stations at lower Miranda River, Pantanal, Mato Grosso do Sul State, Brazil. (1- Braço Morto Acima; 2- Braço Morto Abaixo; 3- Vazante do Morro do Azeite; 4- Baía Cinza).

In "Vazante do Morro do Azeite", with shallow and transparent waters and with abundant rooted and floating aquatic vegetation, the rotenone was used in September, October, November and December of the year 1989. With the impossibility to acquire more rotenone, in the following months the fishes were sampled using castnets with 20 to $30 \mathrm{~mm}$ mesh sizes, with diurnal and nocturnal catches.

In the other three sampling areas, a trawl net, with $33.4 \mathrm{~m}$ long, $6.4 \mathrm{~m}$ high and $16 \mathrm{~mm}$ mesh size was used. In the river dead arms, during the dry season, 3 trawls were made in the same place, while in the flooding season, one was made in a fixed place and two were made in marginal areas, where it was possible to trawl (in the flooding season, littoral areas without vegetation were not so available to trawl). At Baía Cinza, 3 trawls were made in the same places, since great water level fluctuations did not occur due to its isolation. In each station, the maximum water depth was taken in each period of sampling.

The fishes, after identification, using the manual of Britski et al. (1999), were measured (standard lenght), weighed, and guts extracted for food item identification. The guts, preserved in formalin $10 \%$ were opened, and food items identified to the lowest possible taxonomic category. For the evaluation of volume of each food item, the point methods proposed by Hynes (1950), slightly modified by Resende et al. (1996a), were used.

The feeding diet of each species was determined using the methodology of Kawakami \& Vazzoler (1980), expressed as:

$$
\mathrm{IAi}=\mathrm{Fi} \times \underset{\mathrm{i}=1}{\mathrm{n}} \mathrm{i} / \stackrel{\mathrm{a}}{(\mathrm{Fi}} \times \mathrm{Vi})
$$

where

$\mathrm{IAi}=$ feeding index; $\mathrm{i}=1,2, \ldots \mathrm{n}$ food item; $\mathrm{Fi}=$ frequency of occurrence $(\%)$ of food item $\mathrm{i}$; $\mathrm{Vi}=$ volume $(\%)$ of food item $\mathrm{i}$.

The analysis of trophic structure was made using the following procedures:

A trophic guild was considered abundant when its value was higher than the mean value, dividing the number of fish species or the product of $\mathrm{Ni} \times \mathrm{Pi}$ by the number of trophic guilds, in each period and sampling station.

A fish species was considered abundant when its value was higher than the mean value, in the following condition: 


\author{
Abundant fish species $>\mathrm{N} i \times \mathrm{XP}$ x $100 / \AA \mathrm{N} i$ \\ $\mathrm{xP} i$ \\ where \\ $\mathrm{N} i=$ number of fish individuals of $i$ fish \\ species; $\mathrm{P} i=i$ fish species weight. \\ In order to evaluate possible differences on
} frequency of occcurence of trophic guilds (number of species in each trophic guild) and biomass (number of individuals $x$ weight) from one sampling period to another, a non parametric Kruskall-Wallis test was used (Siegel, 1956).

\section{RESULTS}

One hundred and one fish species were caught in the lower Miranda River floodplain, belonging to five orders and 20 families. Applying the methodology proposed by Kawakami \& Vazzoler (1980) for the gut contents found in these species, they could be allocated in nine trophic guilds, defined as follows: 1) omnivorous - fishes that feed on animal and vegetal matters. Insects, plants (terrestrial and aquatic) and microcrustaceans (cladocerans, ostracods, copepods and conchostraceans) are the main food items of these fishes. Algi, thecamoebs, fishes, crustaceans and rotifers are eaten significantly, but less frequently. Occasionally, mollusks, acarins, spiders, briozoans, nematodes, helminthes and fungi are also eaten; 2) herbivorous - fishes that feed on plants, both terrestrial and aquatic, as leaf parts, flowers, fruits, seeds, roots and so on; juveniles may eat algi and small crustaceans like cladocerans; 3 ) detritivorous - fishes that feed on organic detritus, which looks like a soft mud, produced by the decomposition of animal and plant tissues, mainly vegetal (Bowen, 1987), during the process of flooding. In some environments and in some periods of the year, the fishes also feed on algi and microorganisms like rotifers and cladocerans, which occur as epiphytes on the submerged vegetation in the flooding season; 4) ichthyophagous - fishes that feed mainly on fishes, occasionally on small shrimps; 5) lepidophagous - fishes that feed mainly on fish scales; 6) insectivorous - fishes that feed mainly on insects, aquatic, terrestrial or both, such as odonats, dipterans, ephemeropterans, hymenopterans, hemipterans, orthopterans, etc.; 7) zooplanktophagous - fishes that feed on zooplankton, mainly cladocerans; 8) ichthyophagous/insectivorous - fishes that feed on fishes and insects; 9) zooplanktophagous/insectivorous - fishes that can feed on zooplankton or on insects. Detailed information about feeding and food habits of these fishes can be found in Resende et al. (1996b, 1997, 1998a, 1998b) and Pereira \& Resende (1997).

As a whole, 29 species are omnivorous, 16 ichthyophagous, 12 herbivorous, 18 detritivorous, eight zooplanktophagous, seven insectivorous, two lepidophagous, four ichthyophagous/insectivorous and four zooplanktophagous/insectivorous.

Omnivorous and detritivorous trophic guilds predominated in Characiform and Siluriform orders (Table 1). Some trophic guilds occurred only in some orders, as herbivorous, which were restricted to characiforms, while ichthyo/insectivorous, to siluriforms and perciforms. Perciform fishes belong basically to omnivorous and ichthyophagous trophic guilds.

Omnivorous and detritivorous guilds were abundant in the four sampling stations and in all sampling periods (Tables 2 and 3).

Ichthyophagous guild was generally abundant during the decreasing waters and dry period, from September to December. Herbivorous guild was more frequently abundant at Baía Cinza, from September to November/89. Almost half of the species belongs to omnivorous and detritivorous trophic guilds (Tables 4 and 5).

Considering the number of fishes and their weight, the figure is slightly different from that of number of species (Tables 6 and 7). Omnivorous guild continues to be abundant in almost all of the months, detritivorous guild remained abundant at Vazante do Morro do Azeite, and fewer times at Braço Morto Acima and Baía Cinza. Zooplankton/ insectivorous and insectivorous guilds were abundant in some periods in the dead arms, Braço Morto Abaixo and Braço Morto Acima and at Baía Cinza.

Considering the cumulative relative frequency of number of fishes and their weight (Tables 8 and 9), there was no clear predominance of omnivorous and detritivorous guilds. In some cases, the frequency of omnivorous guilds was very low, as in November/89, February/90 and July/90 at Braço Morto Abaixo and in September/89, March/90 and July/90 at Braço Morto Acima. In September/89, at Braço Morto Acima and Baía Cinza, a clear predominance of zooplankton/insectivorous guild was observed. 
TABLE 1

Frequency of trophic guilds by fish orders, in the lower Miranda River, Pantanal, Mato Grosso do Sul State, Brazil.

\begin{tabular}{|c|c|c|c|c|c|c|}
\hline Trophic guilds & \multicolumn{2}{|c|}{ Characiforms } & \multicolumn{2}{c|}{ Siluriforms } & \multicolumn{2}{c|}{ Perciforms } \\
\hline & $\mathbf{N}$ & $\boldsymbol{\%}$ & $\mathbf{N}$ & $\boldsymbol{\%}$ & $\mathbf{N}$ & \% \\
\hline Omnivorous & 10 & 22.2 & 13 & 30.2 & 6 & 54.5 \\
\hline Detritivorous & 8 & 17.8 & 10 & 23.3 & 0 & 0 \\
\hline Ichthyophagous & 9 & 20.0 & 4 & 9.3 & 4 & 36.4 \\
\hline Herbivorous & 12 & 26.7 & 0 & 0 & 0 & 0 \\
\hline Zooplanktophagous & 1 & 2.2 & 7 & 16.3 & 0 & 0 \\
\hline Insetivorous & 1 & 2.2 & 5 & 11.6 & 0 & 0 \\
\hline Zoo/insetivorous & 2 & 4.4 & 2 & 4.6 & 0 & 0 \\
\hline Lepidophagous & 2 & 4.4 & 0 & 0 & 0 & 0 \\
\hline Ichthyo/insetivorous & 0 & 0 & 2 & 4.6 & 1 & 9.1 \\
\hline Total & 45 & & 43 & & & 0 \\
\hline
\end{tabular}

TABLE 2

Number of fish species by trophic guild, by sampling period, at Braço Morto Abaixo and Braço Morto Acima, lower Miranda River, Pantanal, Mato Grosso do Sul State, Brazil (abundant trophic guild in bold).

\begin{tabular}{|c|c|c|c|c|c|c|c|c|c|c|c|}
\hline Trophic guilds & Sep/89 & Oct/89 & Nov/89 & Dec/89 & Jan/90 & Feb/90 & Mar/90 & May/90 & Jul/90 & Sep/90 & Nov/90 \\
\hline & \multicolumn{11}{|c|}{ Braço Morto Abaixo } \\
\hline Omnivorous & 10 & 13 & 12 & 10 & 12 & 5 & 9 & 11 & 2 & 13 & 10 \\
\hline Detritivorous & 5 & 10 & 10 & 11 & 8 & 3 & 4 & 6 & 2 & 8 & 4 \\
\hline Ichthyopagous & 4 & 8 & 7 & 11 & 6 & 2 & 3 & 5 & 1 & 8 & 4 \\
\hline Herbivorous & 3 & 5 & 3 & 5 & 6 & 1 & 3 & 2 & 1 & 6 & 1 \\
\hline Zooplanktophagous & 1 & 2 & 1 & 2 & 1 & 0 & 1 & 2 & 0 & 1 & 0 \\
\hline Insetivorous & 1 & 1 & 1 & 3 & 0 & 0 & 2 & 2 & 0 & 2 & 1 \\
\hline Zoo/insetivorous & 2 & 2 & 2 & 3 & 2 & 2 & 2 & 2 & 2 & 2 & 2 \\
\hline Lepidophagous & 1 & 1 & 1 & 1 & 1 & 0 & 1 & 1 & 0 & 1 & 1 \\
\hline \multirow[t]{2}{*}{ Icht/insetivorous } & 0 & 1 & 2 & 2 & 1 & 0 & 0 & 0 & 0 & 0 & 0 \\
\hline & \multicolumn{11}{|c|}{ Braço Morto Acima } \\
\hline Omnivorous & 8 & 11 & 18 & 11 & 11 & 6 & 14 & 10 & 5 & 16 & 7 \\
\hline Detritivorous & 7 & 12 & 10 & 12 & 10 & 3 & 10 & 9 & 4 & 7 & 8 \\
\hline Ichthyopagous & 9 & 12 & 8 & 10 & 2 & 5 & 8 & 6 & 3 & 10 & 1 \\
\hline Herbivorous & 4 & 3 & 3 & 4 & 3 & 2 & 2 & 3 & 2 & 3 & 2 \\
\hline Zooplanktophagous & 1 & 2 & 1 & 2 & 1 & 0 & 0 & 0 & 0 & 0 & 0 \\
\hline Insetivorous & 3 & 1 & 2 & 1 & 0 & 1 & 1 & 1 & 0 & 1 & 1 \\
\hline Zoo/insetivorous & 2 & 4 & 2 & 3 & 2 & 2 & 2 & 3 & 2 & 2 & 2 \\
\hline Lepidophagous & 1 & 1 & 1 & 1 & 1 & 0 & 2 & 2 & 2 & 1 & 1 \\
\hline Icht/insetivorous & 1 & 1 & 3 & 2 & 0 & 0 & 0 & 1 & 0 & 0 & 0 \\
\hline
\end{tabular}


TABLE 3

Number of fish species by trophic guild, by sampling periods, at Vazante do Morro do Azeite and Baía Cinza, lower Miranda River, Pantanal, Mato Grosso do Sul State, Brazil (abundant trophic guild in bold).

\begin{tabular}{|c|c|c|c|c|c|c|c|c|c|c|c|}
\hline Trophic guilds & Sep/89 & Oct/89 & Nov/89 & Dec/89 & Jan/90 & Feb/90 & Mar/90 & May/90 & Jul/90 & Sep/90 & Nov/90 \\
\hline & \multicolumn{11}{|c|}{ Vazante do Morro do Azeite } \\
\hline Omnivorous & $\mathrm{X}$ & 13 & 11 & 5 & 7 & 0 & 0 & 0 & 5 & 4 & 0 \\
\hline Detritivorous & $\mathrm{X}$ & 9 & 7 & 4 & 5 & 0 & 0 & 3 & 2 & 4 & 2 \\
\hline Ichthyopagous & $\mathrm{X}$ & 7 & 6 & 1 & 1 & 0 & 0 & 0 & 3 & 1 & 0 \\
\hline Herbivorous & $X$ & 5 & 4 & 0 & 1 & 0 & 1 & 1 & 2 & 2 & 0 \\
\hline Zooplanktophagous & $X$ & 0 & 2 & 1 & 0 & 0 & 0 & 0 & 1 & 0 & 0 \\
\hline Insetivorous & $\mathrm{X}$ & 0 & 0 & 0 & 0 & 0 & 0 & 0 & 0 & 1 & 0 \\
\hline Zoo/insetivorous & $\mathrm{X}$ & 2 & 0 & 0 & 0 & 0 & 0 & 0 & 0 & 0 & 0 \\
\hline Lepidophagous & $\mathrm{X}$ & 1 & 0 & 0 & 0 & 0 & 0 & 0 & 0 & 0 & 0 \\
\hline \multirow[t]{2}{*}{ Icht/insetivorous } & $\mathrm{X}$ & 2 & 2 & 1 & 1 & 0 & 0 & 1 & 0 & 0 & 0 \\
\hline & \multicolumn{11}{|c|}{ Baía Cinza } \\
\hline Omnivorous & 12 & 11 & 10 & 7 & 9 & 8 & 7 & 5 & 7 & 6 & 3 \\
\hline Detritivorous & 10 & 10 & 10 & 9 & 10 & 9 & 5 & 6 & 10 & 8 & 5 \\
\hline Ihthyopagous & 7 & 7 & 7 & 3 & 5 & 2 & 6 & 2 & 2 & 2 & 1 \\
\hline Herbivorous & 7 & 5 & 5 & 3 & 1 & 2 & 2 & 0 & 0 & 0 & 0 \\
\hline Zooplanktophagous & 1 & 3 & 3 & 3 & 3 & 1 & 2 & 1 & 1 & 0 & 0 \\
\hline Insetivorous & 1 & 1 & 2 & 2 & 2 & 2 & 1 & 1 & 1 & 0 & 1 \\
\hline Zoo/insetivorous & 2 & 2 & 2 & 2 & 2 & 2 & 2 & 2 & 2 & 1 & 0 \\
\hline Lepidophagous & 1 & 1 & 1 & 1 & 1 & 1 & 1 & 1 & 1 & 1 & 1 \\
\hline Icht/insetivorous & 2 & 2 & 1 & 1 & 2 & 1 & 0 & 1 & 3 & 1 & 1 \\
\hline
\end{tabular}

$\mathrm{X}$ - not sampled

In a general view, considering the total samplings in each station (Table 10) for the species by trophic guild, the omnivorous guild performed one third of the total, followed by detritivorous, ichthyophagous and herbivorous guilds. However, looking at the biomass ( $\mathrm{Ni} \times \mathrm{pi}$ ), although the omnivorous trophic guild was the predominant guild, a so specialized trophic guild as lepidophagous, had a value of $10 \%$, particularly at Braço Morto Abaixo.

A statistical Kruskall-Wallis test (Table 11) showed that the four sampled areas have the same number of species by trophic guild, along the year, except at Vazante Morro do Azeite, and a significant different biomass distribution ( $\mathrm{Ni} \times \mathrm{Pi}$ ) between the trophic guilds.

As for fish species in the dead river arms (Table 12), Braço Morto Abaixo and Braço Morto Acima, the occurrence of abundant omnivorous fishes was high, with species such as Pimelodus argenteus, Pimelodus maculatus, Triportheus spp, Astyanax bimaculatus, Doras sp. 1, Doras sp. 2, Trachydoras paraguayensis and Bujurquina vittata. In Vazante do Morro do Azeite and at Baía Cinza, this frequency was low, and with fewer species, three (Doras sp. 1, Aequidens plagiozonatus and Gymnocorymbus ternetzi) in the first sampling station and only one, Bujurquina vittata, in the second station.

The frequency of occurrence of abundant detritivorous fishes was similar in the dead river arms, with the same species, Liposarcus anisitsi and Curimatella dorsalis. Steindachnerina conspersa was by far the most abundant detritivorous species at Baía Cinza. Prochilodus lineatus, the largest detritivorous fish, was the most abundant at Vazante do Morro do Azeite. 
TABLE 4

Cumulative relative frequency, of species number by trophic guild, by sampling periods, at Braço Morto Abaixo and Braço Morto Acima, Lower Miranda River, Pantanal, Mato Grosso do Sul State, Brazil.

\begin{tabular}{|c|c|c|c|c|c|c|c|c|c|c|c|}
\hline $\begin{array}{l}\mathrm{n}^{\mathbf{0}} \text { species/trophic } \\
\text { guild }\end{array}$ & Sep/89 & Oct/89 & Nov/89 & Dec/89 & Jan/90 & Feb/90 & Mar/90 & May/90 & $\mathbf{J u l} / 90$ & Sep/90 & Nov/90 \\
\hline & \multicolumn{11}{|c|}{ Braço Morto Abaixo } \\
\hline Omnivorous & 37.0 & 30.2 & 30.8 & 20.8 & 32.4 & 38.5 & 36.0 & 35.5 & 25.0 & 31.7 & 43.5 \\
\hline Detritivorous & 56.0 & 53.5 & 56.4 & 43.7 & 54.0 & 61.5 & 52.0 & 54.8 & 50.0 & 51.2 & 60.9 \\
\hline Ichthyopagous & 70.0 & 72.1 & 74.4 & 66.7 & 70.3 & 76.9 & 64.0 & 71.0 & 62.5 & 70.7 & 78.3 \\
\hline Herbivorous & 82.0 & 83.7 & 82.0 & 77.1 & 86.5 & 84.6 & 76.0 & 77.4 & 75.0 & 85.4 & 82.6 \\
\hline Zooplanktophagous & 85.0 & 88.4 & 84.6 & 81.2 & 89.2 & 84.6 & 80.0 & 83.9 & 75.0 & 87.8 & 82.6 \\
\hline Insetivorous & 89.0 & 90.7 & 87.2 & 87.5 & 89.2 & 84.6 & 88.0 & 90.3 & 75.0 & 92.7 & 87.0 \\
\hline Zoo/insetivorous & 96.0 & 95.3 & 92.3 & 93.7 & 94.6 & 100.0 & 96.0 & 96.8 & 100.0 & 97.6 & 95.6 \\
\hline Lepidophagous & 100.0 & 97.7 & 94.9 & 95.8 & 97.3 & 100.0 & 100.0 & 100.0 & 100.0 & 100.0 & 100.0 \\
\hline \multirow[t]{2}{*}{ Icht/insetivorous } & 100.0 & 100.0 & 100.0 & 100.0 & 100.0 & 100.0 & 100.0 & 100.0 & 100.0 & 100.0 & 100.0 \\
\hline & \multicolumn{11}{|c|}{ Braço Morto Acima } \\
\hline Omnivorous & 22.2 & 22.9 & 37.5 & 23.9 & 36.7 & 31.6 & 35.9 & 28.6 & 27.8 & 40.0 & 31.8 \\
\hline Detritivorous & 41.7 & 47.9 & 58.3 & 50.0 & 70.0 & 47.4 & 61.5 & 54.3 & 50.0 & 57.5 & 68.2 \\
\hline Ichthyopagous & 66.7 & 72.9 & 75.0 & 71.7 & 76.7 & 73.7 & 82.0 & 71.4 & 66.7 & 82.5 & 72.7 \\
\hline Herbivorous & 77.8 & 79.2 & 81.2 & 80.4 & 86.7 & 84.2 & 87.2 & 80.0 & 77.8 & 90.0 & 81.8 \\
\hline Zooplanktophagous & 80.6 & 83.3 & 83.3 & 84.8 & 90.0 & 84.2 & 87.2 & 80.0 & 77.8 & 90.0 & 81.8 \\
\hline Insetivorous & 88.9 & 85.4 & 87.5 & 87.0 & 90.0 & 89.5 & 89.7 & 82.9 & 77.8 & 92.5 & 86.4 \\
\hline Zoo/insetivorous & 94.4 & 95.8 & 91.7 & 93.5 & 96.7 & 100.0 & 94.9 & 91.4 & 88.9 & 97.5 & 95.4 \\
\hline Lepidophagous & 97.2 & 97.9 & 93.7 & 95.6 & 100.0 & 100.0 & 100.0 & 97.1 & 100.0 & 100.0 & 100.0 \\
\hline Icht/insetivorous & 100.0 & 100.0 & 100.0 & 100.0 & 100.0 & 100.0 & 100.0 & 100.0 & 100.0 & 100.0 & 100.0 \\
\hline
\end{tabular}

Of the ichthyophagous fishes, only Hoplias malabaricus was abundant at Baía Cinza and none at Vazante do Morro do Azeite. The serrasalmids, Pygocentrus nattereri, Serrasalmus spilopleura and Serrasalmus marginatus, popularly known as "piranhas" were abundant at Braço Morto Abaixo, whereas Hoplias malabaricus and Salminus maxillosus at Braço Morto Acima. Herbivorous fishes (Hemiodus microlepis and Schizodon borelli) were abundant only in the dead river arms. A particular feature of Baía Cinza was the abundance of lepidophagous fish, Roeboides paranensis.

\section{DISCUSSION}

As previously described by Resende \& Palmeira (1999), the majority of the 101 fish species found in the floodplain of lower Miranda River belong to Characiform and Siluriform orders, a general tendency observed in South American freshwater environments (Lowe-McConnell, 1987; Goulding, 1980; Ferreira et al., 1988; BeneditoCecílio, 1994, in Bennemann, 1996; Dias, 1995, in Bennemann, 1996; Bennemann, 1996; TejerinaGarro et al., 1998). One interesting aspect was that some trophic guilds like herbivorous and lepidophagous were found only in Characiform fishes, while almost of the Perciform fishes were omnivorous or ichthyophagous, certainly a consequence of habitat specialization. It is possible to understand why herbivorous aren't found among Siluriforms, since most of them live in the bottom of the rivers. The same is true for lepidophagous fishes: Roeboides paranensis was abundant at Braço Morto Abaixo and particularly at Baía Cinza, a closed and small pond, where the chance to pick scales up from others fishes is easier than in open freshwater environments or even at the bottom of rivers. 
TABLE 5

Cumulative relative frequency, of species number, by trophic guild, by sampling periods, at Vazante do Morro do Azeite and Baía Cinza, lower Miranda River, Pantanal, Mato Grosso do Sul State, Brazil.

\begin{tabular}{|c|c|c|c|c|c|c|c|c|c|c|c|}
\hline $\begin{array}{c}n^{0} \text { species/trophic } \\
\text { guild }\end{array}$ & Sep/89 & Oct/89 & Nov/89 & Dec/89 & Jan/90 & Feb/90 & Mar/90 & May/90 & Jul/90 & Sep/90 & Nov/90 \\
\hline & \multicolumn{11}{|c|}{ Vazante do Morro do Azeite } \\
\hline Omnivorous & $\mathrm{X}$ & 33,3 & 34,4 & 41,7 & 46,7 & 0 & 0 & 0 & 38,5 & 33,3 & 0 \\
\hline Detritivorous & $\mathrm{X}$ & 56,4 & 56,2 & 75,0 & 80,0 & 0 & 0 & 60,0 & 53,8 & 66,7 & 100,0 \\
\hline Ichthyopagous & $\mathrm{X}$ & 74,4 & 75,0 & 83,3 & 86,7 & 0 & 0 & 60,0 & 76,9 & 75,0 & 100,0 \\
\hline Herbivorous & $\mathrm{X}$ & 87,2 & 87,5 & 83,3 & 93,3 & 0 & 100,0 & 80,0 & 92,3 & 91,7 & 100,0 \\
\hline Zooplanktophagous & $\mathrm{X}$ & 87,2 & 93,7 & 91,7 & 93,3 & 0 & 100,0 & 80,0 & 100,0 & 91,7 & 100,0 \\
\hline Insetivorous & $X$ & 87,2 & 93,9 & 91,7 & 93,3 & 0 & 100,0 & 80,0 & 100,0 & 100,0 & 100,0 \\
\hline Zoo/insetivorous & $X$ & 92,3 & 93,7 & 91,7 & 93,3 & 0 & 100,0 & 80,0 & 100,0 & 100,0 & 100,0 \\
\hline Lepidophagous & $\mathrm{X}$ & 94,9 & 93,7 & 91,7 & 93,3 & 0 & 100,0 & 80,0 & 100,0 & 100,0 & 100,0 \\
\hline \multirow[t]{2}{*}{ Icht/insetivorous } & $\mathrm{X}$ & 100,0 & 100,0 & 100,0 & 100,0 & 0 & 100,0 & 100,0 & 100,0 & 100,0 & 100,0 \\
\hline & \multicolumn{11}{|c|}{ Baía Cinza } \\
\hline Omnivorous & 27,9 & 26,2 & 24,4 & 22,6 & 25,7 & 28,6 & 26,9 & 26,3 & 25,9 & 31,6 & 25,0 \\
\hline Detritivorous & 51,2 & 50,0 & 48,8 & 51,6 & 54,3 & 60,7 & 46,1 & 57,9 & 63,0 & 73,7 & 66,7 \\
\hline Ichthyopagous & 67,4 & 66,7 & 65,8 & 61,3 & 68,6 & 67,9 & 69,2 & 68,4 & 70,4 & 84,2 & 75,0 \\
\hline Herbivorous & 83,7 & 78,6 & 78,0 & 71,0 & 71,4 & 75,0 & 76,9 & 68,4 & 70,4 & 84,2 & 75,0 \\
\hline Zooplanktophagous & 86,0 & 85,7 & 85,4 & 80,6 & 80,0 & 78,6 & 84,6 & 73,7 & 74,1 & 84,2 & 75,0 \\
\hline Insetivorous & 88,4 & 88,1 & 90,2 & 87,1 & 85,7 & 85,7 & 88,5 & 78,9 & 77,8 & 84,2 & 83,3 \\
\hline Zoo/insetivorous & 93,0 & 92,9 & 95,1 & 93,5 & 91,4 & 92,9 & 96,1 & 89,5 & 85,2 & 89,5 & 83,3 \\
\hline Lepidophagous & 95,3 & 95,2 & 97,6 & 96,8 & 94,3 & 96,4 & 100,0 & 94,7 & 88,9 & 100,0 & 91,7 \\
\hline Icht/insetivorous & 100,0 & 100,0 & 100,0 & 100,0 & 100,0 & 100,0 & 100,0 & 100,0 & 100,0 & 100,0 & 100,0 \\
\hline
\end{tabular}

$\mathrm{X}$ - not sampled

Almost all of the studied fish species are very opportunistic and generalist as previously observed by Resende et al. (1996, 1997, 1998a, 1998b), probably because specialization is not adaptive to assemblages exploiting seasonal habitats, such as those of the floodplains. Characiforms and Siluriform fishes are more diverse with respect to feeding, since eight and seven trophic guilds were found between them, while only three for Perciform.

Araújo-Lima et al. (1995) found that all trophic guilds, except planktophagous, are well represented in river floodplains, with the detritivorous showing the largest biomass in eight of the 10 studied floodplains. In the Miranda River floodplain, the picture was slightly different, with the dominance of omnivorous and detritivorous fish species which represented, in most cases, more than $50 \%$ of the total number of fish species. In terms of fish biomass, omnivorous and ichthyophagous dominated. Detritivorous were abundant only at Vazante do Morro do Azeite and at Baía Cinza. So, although all of the four sampling station are lenthic water bodies, the distribution of trophic guilds can be different, whether they are dead arms, vazante or isolated pond.

One of the most striking characteristics of fish assemblages in the lower Miranda River was the dominance of omnivorous guild. Similar figures were found in the West-central Mexico streams and rivers (Lyons et al., 1995), Tibagi River in South Brazil (Bennemann, 1996) and at Rondonia State rivers, Brazilian West Amazon (Santos, 1986/1987).

Differences in the frequency of occurrence of abundant species belonging to different trophic guilds probably were the consequences of the peculiarities of each habitat. 
TABLE 6

Ni x Pi of fish species by trophic guild, by sampling periods, at Braço Morto Abaixo and Braço Morto Acima, lower Miranda River, Pantanal, Mato Grosso do Sul State, Brazil (abundant trophic guild in bold).

\begin{tabular}{|c|c|c|c|c|c|c|c|c|c|c|c|}
\hline Trophic guilds & Sep/89 & Oct/89 & Nov/89 & Dec/89 & Jan/90 & Feb/90 & Mar/90 & May/90 & Jul/90 & Sep/90 & Nov/90 \\
\hline & \multicolumn{11}{|c|}{ Braço Morto Abaixo } \\
\hline Omnivorous & 870816 & 96488 & 46954 & 589222 & 61346 & 5817 & 26725 & 82004 & 62 & 848414 & 18080 \\
\hline Detritivorous & 7715 & 23273 & 97553 & 54181 & 4547 & 17399 & 91745 & 1753 & 12 & 61834 & 1988 \\
\hline Ichthyopagous & 14591 & 80438 & 934962 & 445126 & 29876 & 4789 & 44133 & 14307 & 8 & 34015 & 2205 \\
\hline Herbivorous & 6284 & 1260 & 12213 & 9155 & 2877 & 346 & 8068 & 100 & 3660 & 2113 & 3433 \\
\hline ooplanktophagous & 2 & 15 & 17 & 511 & 64 & 0 & 1580 & 64 & 0 & 371 & 0 \\
\hline Insetivorous & 264 & 448 & 6482 & 16839 & 0 & 0 & 2366 & 55310 & 0 & 561 & 9539 \\
\hline Zoo/insetivorous & 44212 & 57622 & 17659 & 52140 & 25840 & 155584 & 38025 & 4339 & 3628 & 193446 & 2026 \\
\hline Lepidophagous & 477 & 447 & 14094 & 77372 & 802 & 0 & 2394 & 21420 & 0 & 12930 & 1856 \\
\hline \multirow[t]{2}{*}{ Icht/insetivorous } & 0 & 16 & 321 & 444 & 1561 & 0 & 0 & 0 & 0 & 0 & 0 \\
\hline & \multicolumn{11}{|c|}{ Braço Morto Acima } \\
\hline Omnivorous & 174173 & 6393260 & 1560887 & 418101 & 266291 & 1824 & 312648 & 123615 & 1948 & 291567 & 126724 \\
\hline Detritivorous & 29532 & 474438 & 24173 & 58610 & 169914 & 3692 & 7254928 & 526944 & 1710 & 25151 & 720347 \\
\hline Ichthyopagous & 81941 & 182480 & 729021 & 102297 & 545 & 4928 & 19583 & 30472 & 17747 & 31349 & 85 \\
\hline Herbivorous & 918 & 2467 & 95374 & 26354 & 326 & 5769 & 10879 & 5338 & 6997 & 10399 & 192 \\
\hline Zooplanktophagous & 20 & 732 & 957 & 283 & 54 & 0 & 0 & 0 & 0 & 0 & 0 \\
\hline Insetivorous & 90807 & 4906 & 6080 & 224 & 0 & 3 & 247 & 150 & 0 & 74525 & 13 \\
\hline Zoo/insetivorous & 7734376 & 103057 & 67857 & 211814 & 24571 & 1744 & 2557 & 12358 & 5430 & 1979 & 3527 \\
\hline Lepidophagous & 3804 & 6276 & 54275 & 35862 & 443 & 0 & 240 & 245 & 64 & 6204 & 0 \\
\hline Icht/insetivorous & 219 & 5 & 2492 & 92 & 0 & 0 & 0 & 53 & 0 & 6204 & 1 \\
\hline
\end{tabular}

At Baía Cinza, where Steindachnerina conspersa, detritivorous and Roeboides paranensis, lepidophagous, were abundant, this may be due to the abundance of organic detritus matter as well as the facility to prey scales on a small and closed water body.

At Vazante do Morro do Azeite, a water body covered with aquatic macrophytes, an abundance of herbivorous guild was expected, but detritivorous guild was abundant, probably because, in this kind of water body, the detritic organic matter comes with the flooding and becomes abundant as a consequence of the filter action of the macrophytes, which means the retention of sediments and organic detritus by the abundant and long macrophytes roots. Generally, herbivorous fishes eat seeds, fruits, flowers and leaves of the riparian vegetation (Resende et al., 1997; Goulding, 1980). The biomass of herbivorous fishes was abundant only in months of flooding, February/ 90 at Braço Morto Acima and July/90, at Braço
Morto Abaixo, when the riparian vegetation is flooded.

The feeding habits of small sized fishes remained largely unknown for a long time, with few exceptions (Ferreira et al., 1988; Araujo-Lima et al., 1986; Hahn et al., 1998). This study made a large contribution to this gap, as a feeding diet of small species, like Moenkhausia dichroura, Psellogrammus kennedyi, Roeboides paranensis, Poptella paraguayensis, Thoracocharax stellatus, Curimatella dorsalis, Trachydoras paraguayensis was determined (Resende et al., 1998a,b). An interesting question is the food diet plasticity of some species like $R$. paranensis and $T$. paraguayensis. $R$. paranensis fed largely on chironomids in the Itaipu Reservoir, Paraná River (Hahn et al., 1998) and on fish scales in the Miranda River (Resende et al., in press). T. paraguayensis fed on cladocerans in the Miranda River (Resende et al., in press) and in the Itaipu Reservoir, on other invertebrates than cladocerans (Hahn et al., 1998). 
TABLE 7

Ni x Pi of fish species by trophic guild, by sampling period, at Vazante do Morro do Azeite and Baía Cinza, lower Miranda River, Pantanal, Mato Grosso do Sul State, Brazil (abundant trophic guild in bold).

\begin{tabular}{|c|c|c|c|c|c|c|c|c|c|c|c|}
\hline Trophic guilds & Sep/89 & Oct/89 & Nov/89 & Dec/89 & Jan/90 & Feb/90 & Mar/90 & May/90 & $\mathrm{Jul} / 90$ & Sep/90 & Nov/90 \\
\hline & \multicolumn{11}{|c|}{ Vazante do Morro do Azeite } \\
\hline Omnivorous & $\mathrm{X}$ & 890548 & 64698 & 1535 & 14781 & 0 & 0 & 0 & 89802 & 131 & 0 \\
\hline Detritivorous & $\mathrm{X}$ & 494241 & 332017 & 237848 & 185110 & 0 & 0 & 142 & 6986 & 191599 & 4315 \\
\hline Ichthyopagous & $\mathrm{X}$ & 21656 & 30502 & 1363 & 100 & 0 & 0 & 0 & 2036 & 3258 & 0 \\
\hline Herbivorous & $\mathrm{X}$ & 32346 & 2603 & 0 & 320 & 0 & 13 & 75 & 1660 & 1256 & 0 \\
\hline Zooplanktophagous & $\mathrm{X}$ & 0 & 254 & 1117 & 0 & 0 & 0 & 0 & 6 & 0 & 0 \\
\hline Insetivorous & $X$ & 0 & 0 & 0 & 0 & 0 & 0 & 0 & 0 & 623 & 0 \\
\hline Zoo/insetivorous & $X$ & 63 & 0 & 0 & 0 & 0 & 0 & 0 & 0 & 0 & 0 \\
\hline Lepidophagous & $X$ & 7 & 0 & 0 & 0 & 0 & 0 & 0 & 0 & 0 & 0 \\
\hline \multirow[t]{2}{*}{ Icht/insetivorous } & $X$ & 5542 & 85988 & 8466 & 1146 & 0 & 0 & 8 & 0 & 0 & 0 \\
\hline & \multicolumn{11}{|c|}{ Baía Cinza } \\
\hline Omnivorous & 174173 & 6393260 & 1560887 & 418101 & 266291 & 1824 & 312648 & 123615 & 1948 & 291567 & 126724 \\
\hline Detritivorous & 29532 & 474438 & 24173 & 58610 & 169914 & 3692 & 7254928 & 526944 & 1710 & 25151 & 720347 \\
\hline Ichthyopagous & 81940 & 182480 & 729021 & 102297 & 545 & 4928 & 19583 & 30472 & 17747 & 31349 & 85 \\
\hline Herbivorous & 918 & 2467 & 95375 & 26345 & 326 & 5769 & 10879 & 5338 & 6997 & 10399 & 192 \\
\hline Zooplanktophagous & 20 & 732 & 957 & 283 & 54 & 0 & 0 & 0 & 0 & 0 & 0 \\
\hline Insetivorous & 90807 & 4906 & 6080 & 224 & 0 & 3 & 247 & 150 & 0 & 74525 & 13 \\
\hline Zoo/insetivorous & 734376 & 103057 & 67857 & 211814 & 24571 & 1744 & 2557 & 12358 & 5430 & 1979 & 3527 \\
\hline Lepidophagous & 3804 & 6276 & 54275 & 35862 & 443 & 0 & 240 & 245 & 64 & 6204 & 1 \\
\hline Icht/insetivorous & 219 & 5 & 2492 & 92 & 0 & 0 & 0 & 53 & 0 & 6204 & 1 \\
\hline
\end{tabular}

$\mathrm{X}=$ not sampled

\section{TABLE 8}

Cumulative relative frequency, of Ni x Pi by trophic guild, at Braço Morto Abaixo and Braço Morto Acima, lower Miranda River, Pantanal, Mato Grosso do Sul State, Brazil.

\begin{tabular}{|c|c|c|c|c|c|c|c|c|c|c|c|c|c|}
\hline $\begin{array}{c}\mathbf{n}^{\mathbf{0}} \text { species/trophic } \\
\text { guild }\end{array}$ & Sep/89 & Oct/89 & Nov/89 & Dec/89 & Jan/90 & Feb/90 & Mar/90 & May/90 & Jul/90 & Sep/90 & Nov/90 \\
\hline & \multicolumn{9}{|c|}{ Braço Morto Abaixo } \\
\hline Omnivorous & 92.2 & 37.1 & 4.1 & 47.3 & 48.3 & 3.2 & 12.4 & 45.7 & 0.8 & 73.5 & 46.2 \\
\hline Detritivorous & 93.0 & 46.1 & 12.8 & 51.7 & 51.9 & 12.6 & 55.1 & 46.7 & 1.0 & 78.9 & 51.3 \\
\hline Ichthyopagous & 94.6 & 77.0 & 95.5 & 87.4 & 75.5 & 15.2 & 75.6 & 54.7 & 1.1 & 81.8 & 56.9 \\
\hline Herbivorous & 95.2 & 77.5 & 96.6 & 88.2 & 77.7 & 15.4 & 79.4 & 54.7 & 50.8 & 82.0 & 65.7 \\
\hline Zooplanktophagous & 95.3 & 77.6 & 97.2 & 89.5 & 77.7 & 15.4 & 80.5 & 54.8 & 50.8 & 82.1 & 65.7 \\
\hline Insetivorous & 95.3 & 77.7 & 97.2 & 89.6 & 77.7 & 15.4 & 81.2 & 85.6 & 50.8 & 82.1 & 90.0 \\
\hline Zoo/insetivorous & 95.3 & 77.7 & 97.2 & 89.6 & 98.1 & 100.0 & 98.9 & 88.0 & 100.0 & 99.0 & 95.3 \\
\hline Lepidophagous & 99.9 & 99.8 & 98.7 & 93.8 & 98.7 & 100.0 & 100.0 & 100.0 & 100.0 & 100.0 & 100.0 \\
\hline Icht/insetivorous & 100.0 & 100.0 & 100.0 & 100.0 & 100.0 & 100.0 & 100.0 & 100.0 & 100.0 & 100.0 & 100.0 \\
\hline
\end{tabular}


TABLE 8 (Continued)

\begin{tabular}{|c|c|c|c|c|c|c|c|c|c|c|c|c|}
\hline $\begin{array}{c}\mathbf{n}^{\mathbf{0}} \text { species/trophic } \\
\text { guild }\end{array}$ & Sep/89 & Oct/89 & Nov/89 & Dec/89 & Jan/90 & Feb/90 & Mar/90 & May/90 & Jul/90 & Sep/90 & Nov/90 \\
\hline & \multicolumn{9}{|c|}{ Braço Morto Acima } \\
\hline Omnivorous & 2.1 & 89.2 & 61.4 & 49.0 & 57.6 & 10.2 & 4.1 & 17.7 & 5.7 & 65.2 & 14.9 \\
\hline Detritivorous & 2.5 & 95.8 & 62.4 & 55.8 & 94.4 & 30.7 & 99.6 & 93.0 & 10.8 & 70.8 & 99.5 \\
\hline Ichthyopagous & 3.5 & 98.4 & 91.1 & 67.8 & 94.5 & 58.1 & 99.8 & 97.4 & 63.1 & 77.8 & 99.5 \\
\hline Herbivorous & 3.5 & 98.4 & 94.8 & 70.9 & 94.6 & 90.3 & 100.0 & 98.2 & 83.8 & 80.1 & 99.6 \\
\hline Zooplanktophagous & 3.5 & 98.4 & 95.1 & 70.9 & 94.6 & 90.3 & 100.0 & 98.2 & 83.8 & 80.1 & 99.6 \\
\hline Insetivorous & 4.6 & 98.5 & 95.1 & 71.0 & 94.6 & 90.3 & 100.0 & 98.2 & 83.8 & 96.8 & 99.6 \\
\hline Zoo/insetivorous & 99.9 & 99.9 & 95.2 & 95.8 & 94.6 & 100.0 & 100.0 & 100.0 & 99.8 & 97.2 & 100.0 \\
\hline Lepidophagous & 100.0 & 100.0 & 97.9 & 100.0 & 99.9 & 100.0 & 100.0 & 100.0 & 100.0 & 98.6 & 100.0 \\
\hline Icht/insetivorous & 100.0 & 100.0 & 100.0 & 100.0 & 100.0 & 100.0 & 100.0 & 100.0 & 100.0 & 100.0 & 100.0 \\
\hline
\end{tabular}

\section{TABLE 9}

Cumulative relative frequency, of Ni x Pi by trophic guild, at Vazante do Morro do Azeite and Baía Cinza, lower Miranda River, Pantanal, Mato Grosso do Sul State, Brazil.

\begin{tabular}{|c|c|c|c|c|c|c|c|c|c|c|c|}
\hline $\begin{array}{c}n^{0} \text { species/trophic } \\
\text { guild }\end{array}$ & Sep/89 & Oct/89 & Nov/89 & Dec/89 & Jan/90 & Feb/90 & Mar/90 & May/90 & $\mathbf{J u l} / 90$ & Sep/90 & Nov/90 \\
\hline & \multicolumn{11}{|c|}{ Vazante do Morro do Azeite } \\
\hline Omnivorous & $\mathrm{X}$ & 61.6 & 12.5 & 0.6 & 7.3 & 0 & 0 & 0 & 89.4 & 0.1 & 0 \\
\hline Detritivorous & $\mathrm{X}$ & 95.9 & 76.9 & 95.6 & 99.2 & 0 & 100.0 & 63.1 & 96.3 & 97.4 & 100.0 \\
\hline Ichthyopagous & $X$ & 97.4 & 82.8 & 96.2 & 99.3 & 0 & 100.0 & 63.1 & 98.3 & 99.0 & 100.0 \\
\hline Herbivorous & $\mathrm{X}$ & 99.6 & 83.3 & 96.2 & 99.4 & 0 & 100.0 & 96.4 & 100.0 & 99.7 & 100.0 \\
\hline Zooplanktophagous & $\mathrm{X}$ & 99.6 & 83.3 & 96.6 & 99.4 & 0 & 100.0 & 96.4 & 100.0 & 99.7 & 100.0 \\
\hline Insetivorous & $\mathrm{X}$ & 99.6 & 83.3 & 96.6 & 99.4 & 0 & 100.0 & 96.4 & 100.0 & 100.0 & 100.0 \\
\hline Zoo/insetivorous & $\mathrm{X}$ & 99.6 & 83.3 & 96.6 & 99.4 & 0 & 100.0 & 96.4 & 100.0 & 100.0 & 100.0 \\
\hline Lepidophagous & $\mathrm{X}$ & 99.6 & 83.3 & 96.6 & 99.4 & 0 & 100.0 & 96.4 & 100.0 & 100.0 & 100.0 \\
\hline \multirow[t]{2}{*}{ Icht/insetivorous } & $X$ & 100.0 & 100.0 & 100.0 & 100.0 & 0 & 100.0 & 100.0 & 100.0 & 100.0 & 100.0 \\
\hline & \multicolumn{11}{|c|}{ Baía Cinza } \\
\hline Omnivorous & 15.6 & 89.2 & 61.4 & 49.0 & 57.6 & 10.2 & 4.1 & 17.7 & 5.7 & 65.2 & 14.9 \\
\hline Detritivorous & 18.3 & 95.8 & 62.4 & 55.8 & 94.4 & 30.7 & 99.6 & 93.0 & 10.8 & 70.8 & 99.5 \\
\hline Ichthyopagous & 25.6 & 98.4 & 91.1 & 67.8 & 94.5 & 58.1 & 99.8 & 97.4 & 63.1 & 77.8 & 99.6 \\
\hline Herbivorous & 25.7 & 98.4 & 94.8 & 70.9 & 94.6 & 90.3 & 100.0 & 98.2 & 83.8 & 80.1 & 99.6 \\
\hline Zooplanktophagous & 25.7 & 98.5 & 94.9 & 70.9 & 94.6 & 90.3 & 100.0 & 98.2 & 83.8 & 80.1 & 99.6 \\
\hline Insetivorous & 33.8 & 98.5 & 95.1 & 71.0 & 94.6 & 90.3 & 100.0 & 98.2 & 83.8 & 96.8 & 99.6 \\
\hline Zoo/insetivorous & 99.6 & 99.9 & 97.8 & 71.0 & 99.9 & 100.0 & 100.0 & 100.0 & 99.8 & 97.2 & 100.0 \\
\hline Lepidophagous & 99.7 & 100.0 & 99.9 & 95.8 & 100.0 & 100.0 & 100.0 & 100.0 & 100.0 & 98.6 & 100.0 \\
\hline Icht/insetivorous & 100.0 & 100.0 & 100.0 & 100.0 & 100.0 & 100.0 & 100.0 & 100.0 & 100.0 & 100.0 & 100.0 \\
\hline
\end{tabular}

$\mathrm{X}$ - not sampled 
TABLE 10

Relative frequency of number of fish species (A) and $\mathrm{Ni} \times \mathrm{Pi}(\mathrm{B})$, by each trophic guild, in each sampling station, lower Miranda River, Pantanal, Mato Grosso do Sul State, Brazil.

\begin{tabular}{|c|c|c|c|c|c|c|c|c|}
\hline \multirow[b]{2}{*}{ Trophic guild } & \multicolumn{2}{|c|}{ B. Morto Abaixo } & \multicolumn{2}{|c|}{ B. Morto Acima } & \multicolumn{2}{|c|}{ V. M. Azeite } & \multicolumn{2}{|c|}{ Baía Cinza } \\
\hline & $\mathbf{A}$ & B & $\mathbf{A}$ & B & $\mathbf{A}$ & B & $\mathbf{A}$ & B \\
\hline Omnivorous & 27.8 & 48.2 & 29.7 & 44.4 & 28.6 & 39.1 & 27.6 & 44.4 \\
\hline Detritivorous & 19.0 & 6.6 & 19.8 & 42.6 & 21.4 & 53.5 & 22.4 & 42.6 \\
\hline Ichthyophagous & 19.0 & 29.3 & 16.5 & 5.5 & 19.6 & 2.2 & 19.0 & 5.5 \\
\hline Herbivorous & 15.2 & 0.9 & 13.2 & 0.8 & 12.5 & 1.4 & 13.8 & 0.8 \\
\hline Zooplanktophagous & 5.1 & 1.7 & 3.3 & 0.8 & 5.4 & 0 & 5.2 & 0.8 \\
\hline Insetivorous & 6.3 & 0 & 6.6 & 0 & 1.8 & 0.1 & 3.4 & 0 \\
\hline Zoo/insetivorous & 3.8 & 0 & 4.4 & 0 & 3.6 & 3.7 & 3.4 & 0 \\
\hline Lepidophagous & 1.3 & 10.8 & 2.2 & 5.4 & 1.8 & 0 & 1.7 & 5.4 \\
\hline Icht/insetivorous & 2.5 & 2.4 & 4.4 & 0.5 & 5.4 & 0 & 3.4 & 0.5 \\
\hline
\end{tabular}

TABLE 11

Results of Kruskall - Wallis analysis for number of species and biomass (Ni x Pi), for the sampled stations.

\begin{tabular}{|c|c|c|c|c|c|c|c|c|}
\hline & \multicolumn{3}{|c|}{ Number of species } & \multicolumn{4}{c|}{ Biomass (Ni x Pi) } \\
\hline & N & R & n & H & N & R & n & H \\
\hline Braço Morto Abaixo & 99 & 11 & 9 & 8,2 & 99 & 11 & 9 & $20,0^{*}$ \\
\hline Braço Morto Acima & 99 & 11 & 9 & 7,8 & 99 & 11 & 9 & $20,4^{*}$ \\
\hline Vazante Morro do Azeite & 81 & 9 & 9 & $16,6^{*}$ & 81 & 9 & 9 & $15,7^{*}$ \\
\hline Baía Cinza & 99 & 11 & 9 & 15,4 & 99 & 11 & 9 & $19,2^{*}$ \\
\hline
\end{tabular}

$\mathrm{N}=$ total number of samplings; $\mathrm{R}=$ number of sampled months; $\mathrm{n}=$ number of samplings.

* significant at $\alpha \leq 0.05$.

It was expected that the number of fish species by trophic guild, mainly in the dead arms and "vazante", were different along the year, as a consequence of water fluctuations, habitat differences and movements of fishes to and out of these environments. However, it was significantly the same along the months in all the sampling stations. The exception was Vazante do Morro do Azeite, but this can be due to the use of different sampling gears. What was significantly different was the biomass between the months, probably due to differences in food availability for the different trophic guilds. Similar pattern was found by Tejerina-Garro et al. (1998) studying the fish community structure in floodplain lakes of the
Araguaia River, in relation to environmental variation as water transparency and maximum depth.

Looking at the emerging scenario, when trophic structure is studied in tropical/subtropical river floodplains, it seems that fishes evolved to use, at a maximum level, the food resources available and almost all of them are generalists in their trophic guilds, a good strategy to survive in such changing or ephemeral habitats. This kind of strategy can be useful for fisheries management purposes, making sure that, even when the fisheries pressure is great and even when the environment changes, they have a chance to continue to exist and to grow. 
TABLE 12

Frequency of occurrence of abundant species, by sampling site and trophic guild.

\begin{tabular}{|c|c|c|c|c|c|}
\hline \multirow{2}{*}{ Species } & \multicolumn{4}{|c|}{ Sampling sites } & \multirow{2}{*}{ Trophic guild } \\
\hline & B. M. Abaixo & B. M. Acima & V. M. Azeite & B. Cinza & \\
\hline Pimelodus argenteus & $\mathbf{X X}$ & $\mathbf{X X X}$ & & & $\mathbf{O}$ \\
\hline Pimelodus maculatus & & $\mathbf{X X}$ & & & $\mathbf{O}$ \\
\hline Triportheus spp & $\mathbf{X X X X X}$ & $\mathbf{X X}$ & & & $\mathbf{O}$ \\
\hline Astyanax bimaculatus & $\mathbf{X}$ & $\mathbf{X}$ & & & $\mathbf{O}$ \\
\hline Doras sp. 1 & $\mathbf{X}$ & $\mathbf{X X X}$ & $\mathbf{X}$ & & $\mathbf{O}$ \\
\hline Doras sp. 2 & $\mathbf{X}$ & $\mathbf{X}$ & & & $\mathbf{O}$ \\
\hline Trachydoras paraguayensis & & $\mathbf{X X}$ & & & $\mathbf{O}$ \\
\hline Aequidens plagiozonatus & & & $\mathbf{X}$ & & $\mathbf{O}$ \\
\hline Gymnocorimbus ternetzi & & & $\mathbf{X}$ & & $\mathbf{O}$ \\
\hline Bujurquina vittata & $\mathbf{X}$ & & & $\mathbf{X X X}$ & $\mathbf{O}$ \\
\hline Liposarcus anisitsi & XXX & XXXXX & $\mathbf{X}$ & $\mathbf{X X}$ & D \\
\hline Curimatella dorsalis & $\mathbf{X X X}$ & $\mathbf{X X}$ & & & D \\
\hline Steindachnerina conspersa & & $\mathbf{X}$ & & XXXXXXXX & D \\
\hline Prochilodus lineatus & & & $\mathbf{X X}$ & $\mathbf{X}$ & D \\
\hline Loricariichthys platymetopon & & & $\mathbf{X}$ & $\mathbf{X X}$ & D \\
\hline Steindachnerina brevipinna & & & & $\mathbf{X X}$ & D \\
\hline Pygocentrus nattereri & $\mathbf{X X}$ & & & & $\mathbf{I}$ \\
\hline Serrasalmus marginatus & $\mathbf{X X}$ & & & & $\mathbf{I}$ \\
\hline Serrasalmus spilopleura & $\mathbf{X X}$ & & & & I \\
\hline Hoplias malabaricus & $\mathbf{X X}$ & $\mathbf{X X}$ & & $\mathbf{X X X}$ & $\mathbf{I}$ \\
\hline Salminus maxillosus & & $\mathbf{X}$ & & & $\mathbf{I}$ \\
\hline Hemiodus microlepis & $\mathbf{X}$ & $\mathbf{X}$ & & & $\mathbf{H}$ \\
\hline Schizodon borelli & & $\mathbf{X}$ & & & $\mathbf{H}$ \\
\hline Eigenmannia trilineata & & $\mathbf{X}$ & & & Z/IN \\
\hline Poptella paraguayensis & $\mathbf{X X X X X}$ & & & $\mathbf{X X X X X}$ & Z/IN \\
\hline Moenckhausia dichroura & $\mathbf{X X X X}$ & $\mathbf{X X}$ & & XXX & $\mathrm{Z} / \mathrm{IN}$ \\
\hline Thoracocharax stellatus & $\mathbf{X X}$ & $\mathbf{X}$ & & & IN \\
\hline Roeboides paranensis & $\mathbf{X X}$ & & & XXXXXXXXX & $\mathbf{L}$ \\
\hline Astronotus ocellatus & & & $\mathbf{X}$ & & I/IN \\
\hline
\end{tabular}

$\mathrm{O}$ = onivorous; $\mathrm{D}$ = detritivorous; $\mathrm{I}$ = ichthyophagous; $\mathrm{H}$ = herbivorous; $\mathrm{Z} / \mathrm{IN}$ = zooplanktophagous/insetivorous; $\mathrm{IN}=$ insetivorous; $\mathrm{L}=$ lepidophagous; $\mathrm{I} / \mathrm{IN}$ = ichthyophagous/insetivorous. 


\section{REFERENCES}

AgOSTinho, A. A., HAHAN, N. S., GOMES, L. C. \& BINI, L. M., 1997, Estrutura trófica. In: A. E. A. M. Vazzoler, A. A. Agostinho \& N. S. Hahn (eds.), A planície de inundação do alto rio Paraná: aspectos físicos, biológicos e socioeconômicos. Maringá, PR, EDUEM, pp. 229-248.

AGOSTINHO, A. A., FERRETTI, C. M. L., GOMES, L. C., HAHN, N. S., SUZUKI, H. I., FUGI, R. \& ABUJANRA, F., 1997, Ictiofauna de dois reservatórios do rio Iguaçu em diferentes fases de colonização: Segredo e Foz de Areia. In: A. A. Agostinho \& L. C. Gomes (eds.), Reservatório de Segredo: bases ecológicas para o manejo. Maringá, PR, EDUEM, pp. 275-292.

ARAUJO-LIMA, C. A. R. M., PORTUGAL, L. P. S. \& FERREIRA, E. G., 1986, Fish-macrophyte relationship in Anavilhanas Archipelago, a black water system in the Central Amazon. J. Fish Biol., 29: 1-12.

ARAUJO-LIMA, C. A. R. M., Agostinho, A. A. \& FABRÉ, N. N., 1995, Trophic aspects of fish communties in Brazilian rivers and reservoirs. In: J. G. Tundisi, C. E. M. Bicudo \& T. Matsumura-Tundisi (eds.), Limnology in Brasil. Rio de Janeiro, ABC/SBL, pp. 105-136.

BENNEMANN, S. T., 1996, Dinâmica trófica de uma assembléia de peixes de um trecho do rio Tibagi (Sertanópolis, Paraná). Tese de Doutorado - Ecologia e Recursos Naturais. Universidade Federal de São Carlos, São Carlos, SP. 142p.

BRITSKI, H. A., SILIMON, K. Z. de S. \& LOPES, B. S., 1999, Peixes do Pantanal. Manual de identificação. Brasília: Embrapa-SPI; Corumbá: Embrapa-CPAP, 184p.

BOWEN, S. H., 1987, Composition and nutritional value of detritus. ICLARM Conference Proceedings, 14. 420p. International Center for Living Aquatic Resources Management, Manila, Philipines, pp. 192-216.

CATElla, A. C., PEIXER, J. \& PALMEIRA, S. da S., 1996, Sistema de Controle da pesca de Mato Grosso do Sul SCPESCA/MS-I maio/1994 a abril/1995. Corumbá, MS: EMBRAPA-CPAPA/SEMADES-MS, 48p. (EMBRAPACPAP, Documentos, 16).

FERREIRA, E. J. G., SANTOS, G. M. \& JEGU, M., 1988, Aspectos ecológicos da ictiofauna do rio Mucajaí, na Ilha Paredão, Roraima, Brasil. Amazoniana, 10(3): 339-352.

GOULDING, M., 1980, The fishes and the forest: explorations in Amazon natural history. Berkeley, University of California Press, Ltd., 280p.

HAHN, N. S., ADRIAN, I. F., FUGI, R., ALMEIDA, V. L. L., 1997, Ecologia trófica. In: A. E. A. M. Vazzoler, A. A. Agostinho \& N. S. Hahn (eds.), A planície de inundação do alto rio Paraná: aspectos físicos, biológicos e socioeconômicos. Maringá, PR, EDUEM, pp. 209-228.

HAHN, N. S., AGOSTINHO, A. A., GOMES, L. C., BINI, L. M., 1998, Estrutura trófica da ictiofauna do Reservatório de Itaipu (Rio Paraná) nos primeiros anos de sua formação. Interciencia, 23(4): 299-305.
HYNES, H. B. N., 1950, The food of freshwater sticklebacks (Gasterostomus aculeatus and Pigosteus pungitius), with a review of methods used in studies of the food of fishes. J. Anim. Ecol., 19(1): 411-429.

LOWE-McCONNELL, R. H., 1987, Ecological studies in tropical fish comunities. Cambridge Univesity Press, 382p.

LYONS, J., NAVARRO-PEREZ, S., COCHRAN, P. A., SANTANA, E. \& GUZMÁN-ARROYO, M., 1995, Index of biotic integrity based on fish assemblages for the conservation of streams and rivers in West-Central Mexico. Cons. Biol., 9(3): 569-584.

KAWAKAMI, E. K. \& VAZZOLER, G., 1980, Método gráfico e estimativa do índice alimentar aplicado no estudo de alimentação de peixes. Bol. Inst. Oceanog., $S$. Paulo, 29(2): 205-207.

MAY, R. M., BEDDINGTON, J. R., CLARK, C. W., HOLT, S. J. \& LAWS, R. M., 1979, Management of multispecies fisheries. Science, 205(4403): 267-277.

PEREIRA, R. A. C. \& RESENDE, E. K. de, 1997, Peixes detritívoros da planície inundável do rio Miranda, Pantanal, Mato Grosso do Sul. Corumbá, MS: EMBRAPA-CPAP (EMBRAPA-CPAP. Boletim de Pesquisa, 12), no prelo.

RESENDE, E. K. de, CATELLA, A. C., NASCIMENTO, F. L., PALMEIRA, S. da S., PEREIRA, R. A. C., LIMA, M. de S. \& ALMEIDA, V. L. L., 1996a, Biologia do curimbatá (Prochilodus lineatus), pintado (Pseudoplatystoma corruscans) e cachara (Pseudoplatystoma fasciatum) na bacia hidrográfica do rio Miranda, Pantanal de Mato Grosso do Sul, Brasil. Corumbá, MS: EMBRAPA-CPAP, 75p. (EMBRAPACPAP. Boletim de Pesquisa, 02).

RESENDE, E. K. de, PEREIRA, R. A. C., ALMEIDA, V. L. L. de \& SILVA, A. G., 1996b, Alimentação de peixes carnívoros da planície inundável do rio Miranda, Pantanal, Mato Grosso do Sul, Brasil. Corumbá, MS: EMBRAPA-CPAP, 36p. (EMBRAPA-CPAP. Boletim de Pesquisa, 03).

RESENDE, E. K. de \& PALMEIRA, S. da S., 1999, Estrutura e dinâmica das comunidades de peixes da planície inundável do rio Miranda, Pantanal, Mato Grosso do Sul, Brasil. Anais do II Simpósio sobre Recursos Naturais e Socioeconômicos do Pantanal. Corumbá; Embrapa Pantanal; pp. 249-282.

RESENDE, E. K. de, PEREIRA, R. A. C. \& ALMEIDA, V. L. L. de, 1997, Peixes herbívoros da planície inundável do rio Miranda, Pantanal, Mato Grosso do Sul, Brasil. Corumbá, MS: EMBRAPA-CPAP, 21p. (EMBRAPACPAP, Boletim de Pesquisa, 10).

RESENDE, E. K. de, PEREIRA, R. A. C., ALMEIDA, V. L. L. de \& SILVA, A. G. da, 1998a, Peixes onívoros da planície inundável do rio Miranda, Mato Grosso do Sul, Brasil. Corumbá, MS: EMBRAPA-CPAP (EMBRAPACPAP. Boletim de Pesquisa, 14). No prelo. 
RESENDE, E. K. de, PEREIRA, R. A. C., ALMEIDA, V. L. L. de Tese de Doutorado - Ecologia e Recursos Naturais. \& SILVA, A. G. da, 1998b, Peixes insetívoros e zooplanctófagos da planície inundável do rio Miranda, Mato Grosso do Sul, Brasil. Corumbá, MS: EMBRAPACPAP (EMBRAPA-CPAP. Boletim de Pesquisa, 15).

SANTOS, G. M. dos, 1986/1987, Composição do pescado e situação da pesca no Estado de Rondônia. Acta Amazônica, 16/17 (único suplemento): 43-84.
SIEGEL, S., 1956, Nonparametric statistcs for the behavioral sciences. McGraw-Hill Kogakusha Ltd., Tokyo, Japan, 312p.

TEJERINA-GARRO, F. L., FORTIN, R., RODRIGUEZ, M. A., 1998, Fish Community structure in relation to environmental variation in floodplain lakes of the Araguaia river, Amazon Basin. Env. Biol. Fishes, 51(4): 399-410. 